\title{
Isolasi dan Identifikasi Morfologi Jamur Selulolitik dari Limbah Rumah Tangga di Desa Sanur Kauh, Bali
}

\author{
Isolation and Morphology Identification of Cellulolytic Fungi from Household Waste in Sanur Kauh Village, Bali
}

\author{
Ni Wayan Sri Sutari* \\ Jurusan Agroekoteknologi, Fakultas Pertanian, Universitas Udayana \\ Jalan P.B. Sudirman, Dangin Puri Klod, Kecamatan Denpasar Barat, Kota Denpasar, Bali 80234 \\ *Email korespondensi: srisutari@unud.ac.id
}

Diterima: 27 Juli 2020 / Disetujui: 29 Agustus 2020

\begin{abstract}
Household organic waste is one of the problems that has not been resolved optimally. Household organic waste is not easy to decompose because the content of lignocellulose as the main component is difficult to decomposed. Cellulolytic fungi is one of the organisms that can degrade cellulose and can accelerate the decomposition of organic waste. The purpose of this research, to find and know the type of cellulolytic fungi from household organic waste in Sanur Kauh Village. Sampling in Sanur Kauh Village, analysis was carried out at the Laboratory of Soil and Environmental Sciences of Udayana University from June to December 2017. The method used was field exploration, laboratory analysis and identification refers to books as well as microscopic and macroscopic observations. The results showed that of 44 isolates resulting from the isolation of fungi from household organic waste that had cellulolytic activity. Isolates which have a high cellulolytic index were isolates of DPN4 3.24 identified as Aspergillus sp. and TWL3 code isolate 2.14 were identified as Trichoderma sp.
\end{abstract}

Keywords: cellulolytic fungi, household organic waste, identification.

\section{ABSTRAK}

Limbah organik rumah tangga menjadi salah satu masalah yang belum teratasi secara maksimal. Limbah organik rumah tangga tidak mudah terdekomposisi karena kandungan lignoselulosa sebagai komponen utama sulit terurai. Jamur selulolitik adalah salah satu organisme yang dapat mendegradasi selulosa dan dapat mempercepat penguraian limbah organik.Tujuan penelitian menemukan dan mengetahui jenis jamur selulolitik dari limbah organik rumah tangga di Desa Sanur Kauh. Pengambilan sampel di Desa Sanur Kauh, analisis dilakukan di Laboratorium Ilmu Tanah dan Lingkungan Universitas Udayana dari bulan Juni sampai Desember 2017. Metode yang digunakan adalah eksplorasi lapangan, analisis laboratorium dan identifikasi mengacu pada buku serta pengamatanmikroskopik dan makroskopik. Hasil penelitian menunjukkan bahwa dari 44 isolat hasil isolasi jamur dari limbah organik rumah tangga yang memiliki aktivitas selulolitik. Isolat yang memiliki indeks selulolitik tinggi adalah isolat Kode DPN4 3,24 teridentifikasi sebagai Aspergillus sp. dan isolat kode TWL3 2,14 teridentifikasi sebagai jamur Trichoderma sp.

Kata kunci: identifikasi jamur, jamur selulolitik, limbah organik rumah tangga.

\section{PENDAHULUAN}

Volume sampah di Kota Denpasar pada tahun 2014 hingga 2016 mengalami peningkatan yaitu 1.247.769 ton, 1.294.696 ton, dan 1.296.438 ton (Data Statistik Dinas Lingkungan Hidup dan Kebersihan Kota Denpasar 2017). Dari data tersebut, Kota Denpasar menghasilkan sampah sebanyak 850 ton per hari. Penumpukan sampah terjadi akibat pengolahan sampah yang belum maksimal. Waktu yang diperlukan sampah organik atau serasah daun sekitar 4 bulan agar terdekomposisi secara alami (Nasrul et al., 2009).

Secara alami di dalam tumpukan sampah tersebut terdapat mikroba yang dapat mendegradasi selulosa. Selulosa dari sisa tumbuhan dan organisme lain diurai oleh mikroba menjadi glukosa, karbondioksida, dan hidrogen yang sangat berguna bagi pertumbuhan tanaman. Pada umumnya, mikroba selulolitik hidup pada lapisan tanah dengan kedalaman 0-30 cm dan bersifat aerop (Roza et al., 2013). Beberapa bakteri, yeast, aktinomisetes, dan jamur dapat menghasilkan selulase (Lynd et al., 2002; Subowo 2015).

Jenis jamur yang memiliki kemampuan mendegradasi serasah dedaunan diantaranya yaitu Trichoderma, Aspergillus, Penicillium, Gliocladium Paecilomyces, Gonatobotryum dan Syncephalastrum (Affandi et al., 2001). Hasil penelitian sebelumnya menunjukkan bahwa Trichoderma viride memiliki kemampuan pendegradasi sampah paling tinggi, kemudian diikuti Aspergillus niger dan Fusarium oxysporum (Kadarmoidheen et al., 2012). Jamur selulolitik berhasil diisolasi dari limbah rumah tangga di Kota Denpasar yang berperan dalam dekomposisi limbah.

Mengingat pentingnya jamur pendegradasi selulosa, maka penelitian ini bertujuan mengisolasi dan mengidentifikasi secara morfologi jamur selulolitik dari limbah rumah tangga. Penelitian ini diharapkan dapat 
menemukan isolat jamur selulolitik dan mendapatkan identitasnya sehingga dapat dimanfaatkan sebagai dekomposer sampah.

\section{BAHAN DAN METODE}

\section{Tempat dan Waktu Penelitian}

Penelitian ini dilaksanakan pada bulan Juni sampai Desember 2017. Pengambilan sampel dilaksanakan di Setiap Dusun di Desa Sanur Kauh, yang terdiri dari 11 Dusun yaitu Dusun Dangin Peken, Dusun Medura, Dusun Abiantimbul, Dusun Tewel, Dusun Puseh, Dusun Pekandelan, Dusun Penopengan, Dusun Belanjong, Dusun Tanjung, Dusun Betngandang, dan Dusun Puseh Kauh. Pelaksanaan isolasi jamur dari limbah organik rumah tangga dilaksanakan di Laboratorium Tanah dan Lingkungan Fakultas Pertanian Universitas Udayana.

\section{Pengambilan Sampel}

Limbah organik rumah tangga yang akan dijadikan sumber isolat mikroorganisme didapatkan dengan cara mengambil limbah organik rumah tangga di setiap dusun di Desa Sanur Kauh. Maing-masing dusun akan dijadikan kode isolat yaitu sebagai berikut: Dusun Dangin Peken (DPN), Dusun Medura (MDR), Dusun Abiantimbul (ABL), Dusun Tewel (TWL), Dusun Puseh (PSH), Dusun Pekandelan (PKN), Dusun Penopengan (PPN), Dusun Belanjong (BLJ), Dusun Tanjung (TJG), Dusun Betngandang (BTG), dan Dusun Puseh Kauh (PSK). Pengambilan sampel limbah organik ruah tangga dilakukan di beberapa titik secara acak dan dikompositkan pada wadah plastik. Sampel dicacah agar ukurannya lebih kecil, kemudian sampel diblender dan digerus menggunakan pistil dan mortal hingga halus. Limbah organik rumah tangga yang telah halus selanjutnya ditimbang sebanyak 10 gram dan dimasukkan kedalam erlenmayer yang telah berisi aquades $90 \mathrm{ml}$. Erlenmayer kemudian ditutup rapat dan dilakukan proses pengocokan suspensi selama 15 menit.

\section{Seri Pengenceran dan Isolasi Jamur}

Seri pengenceran yang digunakan yaitu pengenceran bertingkat. Larutan suspensi dipipet sebanyak $1 \mathrm{ml}$ dimasukkan kedalam tabung reaksi yang berisi larutan fisiologis $9 \mathrm{ml}$. Perbandingan yang digunakan yaitu 1:9. Pengenceran bertingkat yang digunakan untuk isolasi jamur yaitu pengenceran $10^{-2}, 10^{-3}, 10^{-4}$, dan $10^{-5}$. Metode isolasi yang digunakan yaitu metode Pour Plate, masing - masing suspensi dituang ke cawan petri dan ditambahkan media CCRA (Cellulose Congo Red Agar) untuk Masing - masing islolat diberikan kode berdasarkan lokasi pengambilan sampel dan seri pengenceran terhadap sampel tersebut. Isolat selanjutnya diinkubasikan selama 72 jam dalam inkubator dengan suhu $25{ }^{\circ} \mathrm{C}$. Peremajaan isolat dilakukan pada media
CMC (Carboxy Methyl Cellulose) dan diinkumasi selama 48 jam pada suhu ruang.

\section{Uji Kualitatif}

Penapisan isolat dilakukan secara kualitatif dalam kemampuan jamur mendegradasi selulosa. Zona bening yang terbentuk ditetesi kongo merah $0,1 \%$, selanjutnya diinkubasi selama 15 menit. Setelah itu, dicuci menggunakan $\mathrm{NaCl} 0,2 \mathrm{M}$ dan disimpan dalam lemari pendingin selama 24 jam. Selanjutnya dilakukan pengukuran diameter zona bening yang terbentuk disekitar koloni dan diameter koloni. Seleksi dilakukan berdasarkan nisbah zona bening terhadap diameter koloni pada media CMC.

Indeks selulolitik didapatkan melalui pengukuran zona bening yang terbentuk di sekitar koloni jamur. Daya degradasi selulosa diukur berdasarkan indeks selulolitik yang terjadi. Klasifikasi indeks selulolitik tergolong rendah bila nilai IS lebih kecil dari 1, tergolong sedang bila nilai IS antara 1 sampai 2 dan tergolong tinggi apabila nilai IS bila lebih besar dari 2 dan tidak ada reaksi bila tidak terdapat zona bening (Choi et al., 2005). Indeks selulolitik (IS) dapat dihitung dengan rumus sebagai berikut:

$$
\mathrm{IS}=\frac{\text { Diameter zona bening-Diameter Koloni }}{\text { Diameter Koloni }}
$$

\section{Identifikasi Morfologi Jamur}

Jamur selulolitik yang memiliki Indeks selulolitik tinggi diidentifikasi lebih lanjut sedangkan yang memiliki IS sedang dan rendah tidak diidentifikasi. Identifikasi dilaksanakan menggunakan biakan murni berdasarkan karakter makroskopis dan mikroskopis. Jamur selulolitik yang telah murni dibiakkan pada media PDA (Potato Dextrose Agar) untuk diidentifikasi secara makroskopis. Identifikasi mengacu pada buku panduan identifikasi jamur seperti, Pengenalan Kapang Tropik Umum, Microfungi on Miscellanous Substrates, Intoductory Mycology, dan Pictrorial Atlas of Soil and Seed Fungi $3^{\text {rd }}$ Edition (Alexopauluset et al., 1996; Ellis 1988: Gandjar et al., 2006: Watanabe 2010).

\section{HASIL DAN PEMBAHASAN}

\section{Isolasi Jamur Selulolitik}

Hasil uji degradasi selulosa menggunakan uji kualitatif sebanyak 44 isolat jamur yang diisolasi dari sampah rumah tangga. Uji kualitatif dilakukan untuk mengetahui kemampuan jamur dalam mendegradasi selulosa yang ditunjukkan dengan adanya zona bening. Zona bening yang dihasilkan oleh jamur selulolitik dapat dilihat pada Gambar 1. Media CMC merupakan polimer dengan bobot molekul tinggi sehingga tidak dapat ditranspor ke dalam sel mikroorganisme (Kim et al., 2004). 


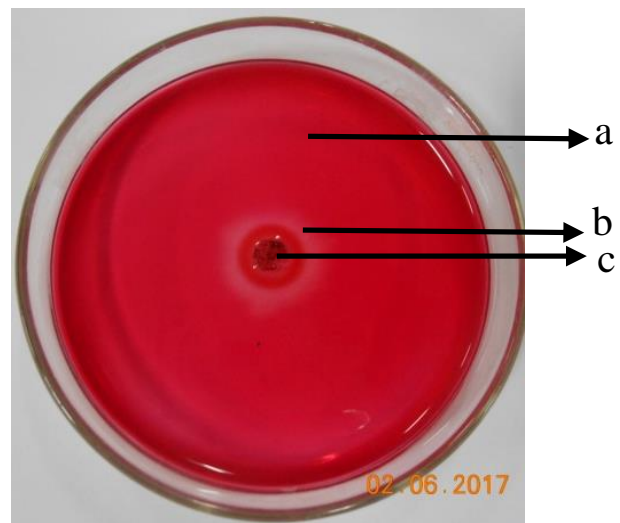

Gambar 1. Koloni jamur selulolitik: (a) medium CMC, (b) zona bening, (c) koloni jamur

Hasil pengukuran isolasi jamur selulolitik dari sampel limbah organik disajikan pada Tabel 1. Semua isolat jamur mampu menghasilkan selulase yang ditunjukkan dengan adanya zona bening yang terbentuk (Tabel 1). Zona bening yang terbentuk disekitar koloni menunjukkan bahwa jamur tersebut mampu mendegradasi selulosa yang terdapat dalam media CMC 1\%. Menurut Haryati (2010) zona bening yang terbentuk merupakan tempat terputusnya ikatan $\beta-1,4$ glikosidik yang menghubungkan monomor D-glukosa pada CMC (Carboxy Methyl Cellulose) merupakan isolat yang memiliki kemampuan dalam mendegradasi selulosa. Indeks selulolitik pada masing-masing isolat jamur berbeda-beda (Tabel 1). Indeks selulolitik yang berbeda menandakan bahwa terdapat perbedaan dari masing-masing isolat dalam menghasilkan enzim selulase untuk menghidrolisis selulosa pada media CMC (Hasanah \& Iwan 2015).

Dari 44 isolat jamur, yang termasuk kriteria IS tinggi hanya $4,55 \%$ dan didominasi oleh IS dengan kriteria rendah (Tabel 2). Sebanyak 2 isolat yang memiliki indeks selulolitik yang tergolong tinggi yaitu dengan kode DPN4 dan TWL3 dengan nilai IS sebesar 3,24 dan 2,14 (Tabel 1). Pada penelitian sebelumnya berhasil mendapatkan isolat jamur dari tanah sawah dengan IS >3,00 yaitu Aspergillus niger, Aspergillus sp., Chaetomium murorum, dan Trichoderma sp. (Reanprayoon et al., 2012). Isolat Jamur yang memiliki indeks selulolitik >3,00 menunjukkan potensi tertinggi untuk menghasilkan selulase (Reanprayoon et al., 2012). Perbedaan indeks selulolitik pada masing-masing isolat dapat disebabkan oleh kemampuan dari masing-masing jamur dalam menghasilkan selulase. Kemampuan jamur mendegradasi CMC mendukung pertumbuhan miselia jamur karena bentuk selulosa yang lebih sederhana yang dapat dihidrolisis dengan mudah (Ezekiel et al., 2010).

\section{Identifikasi Morfologi Jamur}

Dua isolat yang memiliki indeks selulolitik tertinggi selanjutnya diidentifikasi yaitu isolat dengan kode DPN4 yang berasal dari Dusun Dangi Peken dengan pengenceran $10^{-4}$ dan isolat dengan kode TWL3 yang berasal dari Dusun Tewel dengan pengenceran $10^{-3}$.

Hasil pengamatan secara makroskopis isolat Kode DPN4 memiliki koloni yang berwarna hijau kelabu, spora berwarna hijau kelabu, lembut, berbentuk cembung. Secara mikroskopik memiliki ciri-ciri hifa bersepta dan bercabang, konidiofora muncul dari foot cell atau (misellium yang bengkak dan berdinding tebal) membawa sterigma, konidia tumbuh membentuk rantai berwarna hijau (Gambar 2a dan 2b). Jamur isolat Kode DPN4 telah teridentifikasi sebagai Aspergillus sp. Jamur ini tumbuh membentuk koloni mold berserabut, lembut, cembung dan koloni berwarna hijau kelabu, hijau coklat, hitam dan putih serta spora yang dipengaruhi oleh warna koloni tersebut. (Srikandi 1992).

Jamur Aspergillus sp. merupakan salah satu jenis mikroorganisme jamur eukarotik dalam kelas ascomycetes. Aspergillus sp. memiliki ciri-ciri hifa bersepta dan bercabang, konidiofora muncul dari foot cell atau (misellium yang bengkak dan berdinding tebal) membawa sterigma, konidia tumbuh membentuk rantai berwarna hijau, coklat, atau hitam. Aspergilus sp. merupakan jamur yang mampu hidup pada media dengan derajat keasaman dan kandungan gula yang tinggi. Jamur ini dapat menyebabkan pembusukan pada buah-buahan atau sayuran. Hasil penelitian Subowo (2015) menunjukkan bahwa Aspergillus sp. M2P1 setelah ditumbuhkan pada media yang mengandung CMC menunjukkan aktivitas enzim selulase yang paling tinggi di antara jamur yang diuji, sehingga dapat tumbuh lebih baik.

Jamur Isolat Kode TWL3 secara makroskopis menunjukkan permukaan koloni datar, berbentuk bulat, kasar berserat dan bagian tepi yang halus. Awal pertumbuhan koloni berwarna putih, bagian tengah berwarna hijau muda dan berubah menjadi berwarna hijau tua berbentuk lingkaran dengan batas jelas, sedangkan bagian pinggir berwarna putih. Warna koloni mengalami perubahan warna menjadi hijau tua setelah 7 hasi setelah isolasi.

Hasil pengamatan secara mikroskopis isolat Kode TWL3 yaitu hifa bewarna hijau, tangkai fialid pendek, konidia berwarna kehijauan bulat tumbuh pada ujung dan ada juga konidium terbentuk secara bergerombol berwarna hijau muda pada permukaan sel konidiofornya (Gambar 2c). Fialid memiliki ukuran panjang $\pm 11,3 \mu$ dan cabang konidiofor panjangnya $\pm 13,5 \mu$. Adanya banyak percabangan konidiofor yang menyerupai piramid yaitu cabang yang lebih panjang di bawahnya, fialid tersusun pada kelompok-kelompok yang berbeda, terdapat 2-3 fialid tiap kelompok. Jamur isolat TWL3 telah teridentifikasi sebagai Trichoderma sp.

Tabel 1. Indeks Selulolitik (IS) Jamur Selulolitik dari Limbah Organik Rumah tangga di desa Sanur Kauh 


\begin{tabular}{|c|c|c|c|c|c|}
\hline \multirow[t]{2}{*}{ Lokasi } & \multirow[t]{2}{*}{ Kode Isolat } & \multicolumn{2}{|c|}{ Diameter (mm) } & \multirow[t]{2}{*}{ Indeks Selulolitik (mm) } & \multirow[t]{2}{*}{ Ket. } \\
\hline & & Zona Bening & Koloni & & \\
\hline \multirow[t]{4}{*}{ Dangin Peken } & DPN2 & 21,3 & 11,5 & 0,85 & Rendah \\
\hline & DPN3 & 15,3 & 9,2 & 0,66 & Rendah \\
\hline & DPN4 & 28,0 & 6,6 & 3,24 & Tinggi \\
\hline & DPN5 & 27,5 & 13,2 & 1,08 & Sedang \\
\hline \multirow[t]{4}{*}{ Dusun Medura } & MDR2 & 45,2 & 18,8 & 1,40 & Rendah \\
\hline & MDR3 & 20,1 & 9,6 & 1,09 & Sedang \\
\hline & MDR4 & 13,0 & 7,8 & 0,67 & Rendah \\
\hline & MDR5 & 15,2 & 7,2 & 1,11 & Sedang \\
\hline \multirow[t]{4}{*}{ Dusun Abiantimbul } & ABT2 & 63,3 & 50,2 & 0,26 & Rendah \\
\hline & ABT3 & 64,3 & 50,1 & 0,28 & Rendah \\
\hline & ABT4 & 50,5 & 26,6 & 0,90 & Rendah \\
\hline & ABT5 & 61,2 & 42,7 & 0,43 & Rendah \\
\hline \multirow[t]{4}{*}{ Dusun Tewel } & TWL2 & 56,5 & 49,8 & 0,13 & Rendah \\
\hline & TWL3 & 22,3 & 7,1 & 2,14 & Tinggi \\
\hline & TWL4 & 45,5 & 40,1 & 0,13 & Rendah \\
\hline & TWL5 & 32,4 & 15,8 & 1,05 & Sedang \\
\hline \multirow[t]{4}{*}{ Dusun Puseh } & PSH2 & 17,6 & 9,8 & 0,80 & Rendah \\
\hline & PSH3 & 23,1 & 11,5 & 1,01 & Sedang \\
\hline & PSH4 & 35,1 & 14,7 & 1,39 & Sedang \\
\hline & PSH5 & 33,1 & 12,9 & 1,57 & Sedang \\
\hline \multirow[t]{4}{*}{ Dusun Pekandelan } & PKD2 & 49,2 & 16,6 & 1,96 & Sedang \\
\hline & PKD3 & 45,6 & 21,3 & 1,14 & Sedang \\
\hline & PKD4 & 26,6 & 17,1 & 0,56 & Rendah \\
\hline & PKD5 & 22,5 & 11,7 & 0,92 & Rendah \\
\hline \multirow[t]{4}{*}{ Dusun Penopengan } & PNG2 & 22,7 & 8,7 & 1,61 & Sedang \\
\hline & PNG3 & 34,3 & 18,8 & 0,82 & Rendah \\
\hline & PNG4 & 45,0 & 22,1 & 1,04 & Sedang \\
\hline & PNG5 & 44,2 & 25,3 & 0,75 & Rendah \\
\hline \multirow[t]{4}{*}{ Dusun Belanjong } & BLJ2 & 36,4 & 17,8 & 1,04 & Sedang \\
\hline & BLJ3 & 45,2 & 25,4 & 0,78 & Rendah \\
\hline & BLJ4 & 27,6 & 20,4 & 0,35 & Rendah \\
\hline & BLJ5 & 38,1 & 18,2 & 1,09 & Sedang \\
\hline \multirow[t]{4}{*}{ Dusun Tanjung } & TNG2 & 28,2 & 16,1 & 0,75 & Rendah \\
\hline & TNG3 & 34,2 & 17,6 & 0,94 & Rendah \\
\hline & TNG4 & 36,3 & 18,7 & 0,94 & Rendah \\
\hline & TNG5 & 21,6 & 11,5 & 0,88 & Rendah \\
\hline \multirow[t]{4}{*}{ Dusun Betngandang } & BTG2 & 18,1 & 11,2 & 0,62 & Rendah \\
\hline & BTG3 & 39,6 & 15,8 & 1,51 & Sedang \\
\hline & BTG4 & 35,3 & 17,2 & 1,05 & Sedang \\
\hline & BTG5 & 29,7 & 14,9 & 0,99 & Rendah \\
\hline \multirow[t]{4}{*}{ Dusun Puseh Kauh } & PHK2 & 45,3 & 20,7 & 1,19 & Sedang \\
\hline & PHK3 & 38,3 & 16,8 & 1,28 & Sedang \\
\hline & PHK4 & 29,6 & 17,9 & 0,65 & Rendah \\
\hline & PHK5 & 35,4 & 18,8 & 0,88 & Rendah \\
\hline \multicolumn{6}{|c|}{ Tabel 2. Persentase indeks selulolitik dari 44 isolat jamur selulolitik } \\
\hline Kriteria & \multicolumn{2}{|c|}{ Nilai IS } & Jumlah isolat & \multicolumn{2}{|l|}{ Persentase $(\%)$} \\
\hline Tinggi & \multicolumn{2}{|c|}{$<1$} & 2 & \multicolumn{2}{|c|}{4,55} \\
\hline Sedang & $1 \geq \mathrm{x}$ & & 17 & 38,64 & \\
\hline Rendah & $>2$ & & 25 & 56,81 & \\
\hline
\end{tabular}




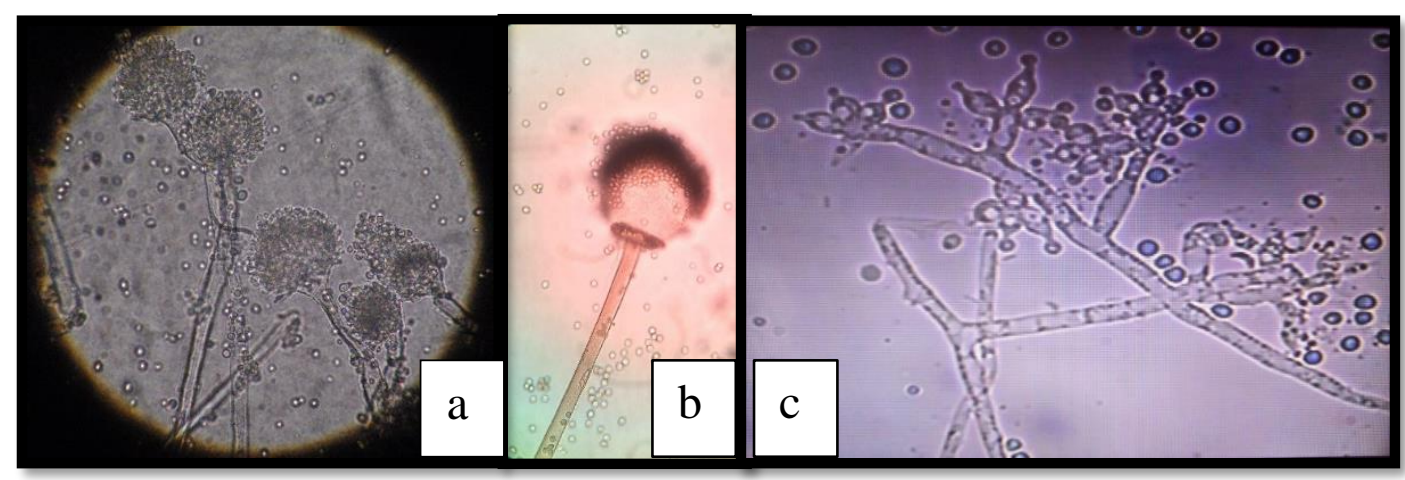

Gambar 2. Morfologi jamur secara mikroskopis pada media PDA: (a) genus Aspergillus sp. perbesaran 100x, (b) genus Aspergilus sp. Perbesaran 400x, dan (c) genus Trichoderma sp. Perbesaran 400x

Trichoderma sp. merupakan mikroorganisme tanah bersifat saprofit yang secara alami menyerang cendawan patogen dan bersifat menguntungkan bagi tanaman. Jamur Trichoderma sp. merupakan salah satu jenis jamur yang banyak dijumpai hampir pada semua jenis tanah dan pada berbagai habitat yang merupakan salah satu jenis jamur yang dapat dimanfaatkan sebagai agens hayati pengendali patogen tanah. Jamur ini dapat berkembang biak dengan cepat pada daerah perakaran tanaman. Spesies Trichoderma sp. berperan sebagai organisme pengurai dan agens hayati. Manfaat lainnya dari Aspergilus sp. dan Trichoderma sp. yaitu dapat digunakan untuk pengolahan pakan ternak dari limbah padat bioetanol (Suryani et al., 2012). Keduanya memiliki daya selulolitik yang cukup tinggi, sehingga dapat meningkatkan kandungan protein, energi, bahan kering dan mampu mendegradasi serat kasar pada limbah padat bioetanol sehingga mutu limbah menjadi lebih baik untuk dikonsumsi ternak (Suryani et al., 2012).

\section{KESIMPULAN}

Sebanyak 44 isolat hasil isolasi dari limbah organik rumah tangga di Desa sanur Kauh yang mampu mendegradasi selulosa pada media CMC dan ditunjukkan dengan adanya zona bening. Terdapat 2 isolat yang memiliki IS tinggi yaitu isolat kode DPN4 dan TWL3 dengan nilai IS 3,24 dan 2,14. Isolat kode DPN4 teridentifikasi sebagai Aspergillus sp. dan kode TWL3 adalah Trichoderma sp.

\section{DAFTAR PUSTAKA}

Affandi, M. (2001). Diversitas dan visualisasi karakter jamur yang berasosiasi dengan proses degradasi serasah di lingkungan mangrove. Universitas Airlangga.

Alexopoulos, C.J., Mims, C.W., \& Blackwell, M. (1996). Introductory mycology fourth edition. John Wiley \& Sons.

Choi, Y. J., Lee, J. S., Lee, H. B., \& Kim, H. J. (2018). “First report of leaf blight caused by Curvularia verruculosa on Zoysiagrass (Zoysia japonica) in
Korea. The American Phytopathological Society, 102(6), 1173.

Data Statistik Dinas Lingkungan Hidup dan Kebersihan Kota Denpasar. (2017). Lampiran rekapitulasi volume sampah kota Denpasar tahun 2015, 2016 dan 2017. Denpasar: Statistik Kota Denpasar.

Ezekiel, C. N., Odebode, A. C., Omenka, R. O., \& Adesioye, F. A. (2010). Growth response and comparative cellulase induction in soil fungi grown on different cellulose media. Acta Atech, 3(2), 52-59.

Gandjar, I. W., Sjamsuridzal, \& Oetari, A. (2006). Mikologi dasar dan terapan. DKI Jakarta: Yayasan Obor Indonesia.

Haryati, T., Marbun, P. A., \& Purwadaria, T. (2010). Preservasi xilanase Bacillus pumilus PU4-2 dengan teknik imobilisasi pada pollard dan penambahan kation. Mikrobiol Indonesia, 15(1), 63-71.

Hasanah, N., \& Iwan, S. (2015). Aktivitas selulase isolat jamur isolat jamur dari limbah media tanam jamur merang. Pros Sem Nas Masy Biodiv Indon, 1(5), 1110-1115.

Kadarmoidheen, M., Saranraj, P., \& Stella, D. (2012). Effect of cellulolytic fungi on the degradation of cellulosic agricultural wastes. Intl J Appl Microbil Scipub, 1(2), $13-23$.

Kim, K. C., Seong-Soo, Y., Oh Young A., \& Seong-Jun K. (2003). Isolation and characteristics of Trichoderma harzianum FJ1 producting cellulase and xyanase. $J$ Microbiol Biotechnol, 13(1), 1-8.

Lynd, L. R., Weimer, P. J., Zyl, W. H. V., \& Pretorius, I. S. (2002). Microbial cellulose utilization: fundamentals and biotechnology. Microbiology and Molecular Biology Reviews, 66(3), 506-577. 
Nasrul, T. M. (2009). Pengaruh penambahan jamur pelapuk putih pada proses pengomposan tandan kosong kelapa sawit. Jurnal Rekayasa Kimia dan Lingkungan, 7(2), 194-199.

Reanprayoon, P., \& Wattanachai, P. (2012). Tropical soil fungi producing cellulase and related enzymes in biodegradation. Jurnal of Applied Sciences, 12(18): 1909-1916.

Roza, R.M., Martina, A., Fibriarti, B. L., Zul, D., \& Ramadhan, N. (2013). Isolasi dan seleksi jamur selulolitik dari tanah gambut di perkebunan karet desa Rimbo Panjang kabupaten Kampar Riau. Prosiding Semirata FMIPA Universitas Lampung, 13(2), 263-266.
Srikandi, F. (1992). Mikrobiologi pangan I. Jakarta: Gramedia Pustaka Utama.

Subowo, Y. B. (2015). Isolasi dan seleksi jamur tanah pengurai selulosa dari berbagai lingkungan. Pros Semnas Masybiodivindon, 1(3), 423-427.

Watanabe, T. (2010). Pictorial atlas of soil and seed fungi morphologies of cultured fungi and key of species 3nd. Taylor \& Francis Group.

Suryani, Y., Andayaningsih, P., Hernaman, I. (2012). Isolasi dan identifikasi jamur selulolitik pada limbah produksi bioetanol dari singkong yang berpotensi dalam pengolahan limbah menjadi pakan domba. Jurnal Istek, 6(2), 1-10. 